\title{
Gene Frequency and Heritability of Rh Blood Group Gene in 44 Human Populations
}

\author{
Supriyo CHAKRABORTY \\ Assam University, Department of Biotechnology, Silchar 788011, Assam, India; supriyoch_2008@rediffmail.com
}

\begin{abstract}
The frequency of RhD and Rhd alleles of Rh blood group gene was estimated in 44 human populations distributed all over the world from the RhD phenotypic data. The average frequency of RhD and Rhd allele over these populations was 0.70 and 0.30 , respectively. Higher frequency of RhD allele than the expected estimate (0.50) in all the populations, under Hardy-Weinberg equilibrium condition assuming equal frequency of both alleles in the initial population, indicated inbreeding at $\mathrm{RhD} / \mathrm{d}$ locus as well as natural selection for RhD allele. Very high heritability estimate (84.04\%) of Rh allele frequency revealed that this trait was under weak selection pressure and resulted in greater genetic variation in existing populations. It is consistent with Fisher's fundamental theorem of natural selection. The results from the present study suggest that inbreeding at $\mathrm{RhD} / \mathrm{d}$ locus and some other factors (possibly mutation, migration and genetic drift) other than natural selection alone played major roles in changing the Rh allele frequency in these populations.
\end{abstract}

Keywords: gene frequency, heritability, human populations, Rh gene

\section{Introduction}

Rh system is one of the most complex human blood group systems and it is genetically controlled. In identification and transfusion practices, Rh blood group typing in man is routinely done. Human beings are broadly categorized as $\mathrm{Rh}+\mathrm{ve}$ and $\mathrm{Rh}$ - ve following blood tests depending on the presence or absence of Rh-antigen or Dantigen. The term Rh was coined from the Rhesus monkey in which the blood antigen was first detected. An Rh +ve individual produces $\mathrm{D}$-antigen whereas the $\mathrm{Rh}-\mathrm{ve}$ individual fails to produce $\mathrm{D}$-antigen on $\mathrm{RBC}$. D-antigen (Rho) is clinically the most important in the Rh system because it is highly antigenic. Other common Rh antigens are $\mathrm{C}, \mathrm{c}, \mathrm{E}$ and e. These are less immunogenic than the $\mathrm{D}$ antigen. $\mathrm{D}$ is considered to be the most potent immunogen followed by c and E. About $100 \mathrm{Rh}$ antigens have been discovered so far.

The genes of the Rh system are located on chromosome 1 of human genome. The inheritance of Rh genes is highly complex. Two major theories i.e. Fisher-Race system and Weiner system have been put forward to explain the inheritance of Rh system. Fisher and Race postulated the theory of 3 closely linked genes C, D and $\mathrm{E}$ with their corresponding recessive alleles $\mathrm{c}, \mathrm{d}$ and $\mathrm{e}$ in governing the $\mathrm{Rh}$ system. But the allele $d$ has not yet been identified. Weiner system favored the multiple allelic series at one locus governing the Rh system. Neither the Fisher- Race nor the Weiner concept has any practical significance in laboratory work (Saran, 2003) and individual identification. So the phenotype of the Rh system of an individual is determined in a routine test depending on the expression of $\mathrm{D}$-antigen on
$\mathrm{RBC}$ using anti-RhD sera. The genotype of an individual with respect to $\mathrm{Rh}$ system cannot be precisely predicted mainly due to the non-existence of $d$ antigen and the difficulty in determining the arrangement of the genes in two homologues of chromosome 1 of a normal diploid.

Since the presence or absence of $\mathrm{D}$-antigen on $\mathrm{RBC}$ is routinely tested, it is assumed for the sake of genetic analysis that a single gene with two alleles (RhD, Rhd) showing dominance governs the expression of $\mathrm{D}$-antigen. $\mathrm{Rh}+\mathrm{ve}$ phenotype will be exhibited by dominant homozygote ( $\mathrm{RhD} / \mathrm{RhD}$ ) and heterozygote ( $\mathrm{RhD} / \mathrm{Rhd}$ ) whereas $\mathrm{Rh}$ -ve genotype by recessive homozygote (Rhd/Rhd).

$\mathrm{RhD}$ phenotyping data of a population are generated to estimate the frequency of these alleles in the population to characterize it. The proportions of different alleles of a gene in a panmictic population are known as allele or gene frequency (Singh, 1990). The present study was undertaken to estimate the frequencies of two alleles $(\mathrm{RhD}$ and Rhd) from the RhD phenotyping data of 44 human populations collected from diverse sources to characterize these populations and to estimate the heritability (broad sense) of gene frequency of Rh system. The term gene frequency in population genetics is treated as a mean and so it is used in various genetic and biostatistical analyses.

\section{Materials and methods}

RhD phenotyping data showing the distribution of $\mathrm{Rh}+\mathrm{ve}$ and $\mathrm{Rh}$-ve groups in 44 human populations/races were collected from diverse sources as shown in Tab. 1. These data sources included published papers and websites. The $\mathrm{RhD}$ phenotyping data of each population were 
Tab. 1. Estimates of RhD and Rhd allele frequencies of Rh gene in 44 world populations

\begin{tabular}{|c|c|c|c|c|c|}
\hline \multirow{2}{*}{ Sl. No. } & \multirow{2}{*}{ Population / Ethnic Group } & \multicolumn{2}{|c|}{ Allele Frequency } & \multirow{2}{*}{ Total } & \multirow{2}{*}{ Reference* $^{*}$} \\
\hline & & RhD & Rhd & & \\
\hline 1 & Argentina & 0.70 & 0.30 & 1.00 & www.reference for bl type \\
\hline 2 & Australia & 0.56 & 0.44 & 1.00 & - do - \\
\hline 3 & Austria & 0.56 & 0.44 & 1.00 & - do - \\
\hline 4 & Arabs (Lebanon) & 0.67 & 0.33 & 1.00 & Mourant et al., 1976 \\
\hline 5 & Bengalis (Kolkata) & 0.78 & 0.22 & 1.00 & - do - \\
\hline 6 & Belgium & 0.78 & 0.22 & 1.00 & www.reference for bl type \\
\hline 7 & Baluchistan (Pak) & 0.78 & 0.22 & 1.00 & Khattak et al., 2008 \\
\hline 8 & Britain (UK) & 0.59 & 0.41 & 1.00 & Khattak et al., 2008 \\
\hline 9 & Barak Valley (Hindus) & 0.83 & 0.17 & 1.00 & Chakraborty, 2010 \\
\hline 10 & Barak Valley (Muslims) & 0.86 & 0.14 & 1.00 & - do - \\
\hline 11 & Brazil & 0.56 & 0.44 & 1.00 & www.blood type facts \\
\hline 12 & China (Beijing) & 0.90 & 0.10 & 1.00 & Mourant et al., 1976 \\
\hline 13 & Canada & 0.60 & 0.40 & 1.00 & www.reference for bl type \\
\hline 14 & Denmark & 0.60 & 0.40 & 1.00 & - do - \\
\hline 15 & Estonia & 0.64 & 0.36 & 1.00 & www.blood type facts \\
\hline 16 & Eskimo (Alaska) & 1.00 & - & 1.00 & Mourant et al., 1976 \\
\hline 17 & France & 0.61 & 0.39 & 1.00 & www.reference for bl type \\
\hline 18 & Finland & 0.64 & 0.36 & 1.00 & - do- \\
\hline 19 & Guinea (France) & 0.80 & 0.20 & 1.00 & Loua et al., 2007 \\
\hline 20 & Germany & 0.61 & 0.39 & 1.00 & www.blood type facts \\
\hline 21 & Hong Kong & 0.90 & 0.10 & 1.00 & www.reference for bl type \\
\hline 22 & Iceland & 0.61 & 0.39 & 1.00 & www.blood type facts \\
\hline 23 & Ireland & 0.60 & 0.40 & 1.00 & - do - \\
\hline 24 & Israel & 0.68 & 0.32 & 1.00 & - do - \\
\hline 25 & India (General) & 0.76 & 0.24 & 1.00 & Khattak et al., 2008 \\
\hline 26 & Kenya & 0.81 & 0.19 & 1.00 & Khattak et al., 2008 \\
\hline 27 & Korea (South) & 0.95 & 0.05 & 1.00 & www.reference for bl type \\
\hline 28 & Mexico & 0.58 & 0.42 & 1.00 & Mourant et al., 1976 \\
\hline 29 & Nigeria & 0.79 & 0.21 & 1.00 & Khattak et al., 2008 \\
\hline 30 & Netherlands & 0.60 & 0.40 & 1.00 & www.reference for bl type \\
\hline 31 & Norway & 0.62 & 0.38 & 1.00 & www.blood type facts \\
\hline 32 & New Zealand & 0.58 & 0.42 & 1.00 & - do - \\
\hline 33 & Peswar (Pak) & 0.77 & 0.23 & 1.00 & Khattak et al., 2008 \\
\hline 34 & Poland & 0.61 & 0.39 & 1.00 & www.reference for bl type \\
\hline 35 & Portugal & 0.63 & 0.37 & 1.00 & www.blood type facts \\
\hline 36 & Red Indians (Canada) & 0.86 & 0.14 & 1.00 & Mourant et al., 1976 \\
\hline 37 & Saudi Arabia & 0.74 & 0.26 & 1.00 & Khattak et al., 2008 \\
\hline 38 & Spain & 0.57 & 0.43 & 1.00 & www.blood type facts \\
\hline 39 & Sudan & 0.74 & 0.26 & 1.00 & www.ncbi.nlm.nih.gov \\
\hline 40 & Sweden & 0.60 & 0.40 & 1.00 & www.reference for bl type \\
\hline 41 & Swat (Pak) & 0.90 & 0.10 & 1.00 & Khattak et al., 2008 \\
\hline 42 & Sindh (Pak) & 0.71 & 0.29 & 1.00 & - do - \\
\hline 43 & Turkey & 0.67 & 0.33 & 1.00 & www.blood type facts \\
\hline \multirow[t]{2}{*}{44} & USA & 0.61 & 0.39 & 1.00 & Khattak et al., 2008 \\
\hline & Average & 0.70 & 0.30 & 1.00 & \\
\hline
\end{tabular}

${ }^{*}$ Detailed reference in text

then used to estimate the frequency of two alleles $(\mathrm{RhD}$, Rhd) in each population following the formulae suggested by Hedrick (2005). In the present study it was assumed that $\mathrm{RhD}$ antigen production in $\mathrm{RBC}$ is governed by a single gene with two alleles showing complete dominance.
Since gene frequency is treated as a mean in population genetics, the analysis of variance (one way) on the estimated frequencies of $\mathrm{RhD}$ and Rhd alleles over $44 \mathrm{popu}-$ lations was carried out as per Gupta (1991). Genotypic variance, environmental variance and phenotypic variance 
18

of the Rh gene frequency were estimated using the expected mean squares given in Tab. 2. Heritability (broad sense) of the Rh gene frequency was calculated as per Johnson et al. (1955).

\section{Results and discussion}

The estimates of $\mathrm{RhD}$ and Rhd alleles in 44 world populations are presented in Tab. 1. The average frequency of $\mathrm{RhD}$ and Rhd alleles in these populations was 0.70 and 0.30 respectively. Theoretically, the frequencies of both $\mathrm{RhD}$ and Rhd alleles should be equal to 0.50 in HardyWeinberg equilibrium assuming the occurrence of both the alleles in equal frequencies in the starting population. In the existing populations the $\mathrm{RhD}$ allele on an average occurred 2.33 fold more than Rhd allele indicating that inbreeding might have occurred in $\mathrm{RhD} / \mathrm{d}$ locus, thereby increasing the frequency of $\mathrm{RhD}$ allele. This increase could also result from the natural selection for $\mathrm{RhD}$ allele in these populations. In the Eskimos (Alaska), the RhD allele was fixed as revealed by the allele frequency value of unity.

The analysis of variance (one way ANOVA) for the allele frequency of Rh gene (Tab. 2) revealed that the two blood groups of Rh system differed between themselves at $\mathrm{p}=0.01$ indicating that these two blood groups are genetically different. It was indicated by the F test value of 240.41 of "between blood groups" variation at 1, 86 degrees of freedom. Genotypic variance and phenotypic variance for Rh allele frequency (Tab. 3) were estimated using the expected mean squares shown in Tab. 2. The difference between genotypic and phenotypic variance for Rh allele frequency was very small indicating the predominant role of genes and simultaneously the insignificant role of environment in determining the $\mathrm{Rh}$ allele frequency.

Tab. 2. Analysis of variance for allele frequency of Rh gene in 44 populations

\begin{tabular}{ccccc}
\hline $\begin{array}{c}\text { Source of } \\
\text { variation }\end{array}$ & df & $\begin{array}{c}\text { Mean } \\
\text { squares }\end{array}$ & $\begin{array}{c}\mathrm{F} \\
\text { value }\end{array}$ & $\begin{array}{c}\text { Expected } \\
\text { mean squares }\end{array}$ \\
\hline $\begin{array}{c}\text { Between Blood } \\
\text { Groups }(\mathrm{BG})\end{array}$ & 1 & 3.150 & $240.41^{*}$ & $\mathrm{~V}(\mathrm{WG})+\mathrm{nV}(\mathrm{BG})$ \\
$\begin{array}{c}\text { Within Blood } \\
\text { Groups }(\mathrm{WG})\end{array}$ & 86 & 0.015 & - & $\mathrm{V}(\mathrm{WG})$ \\
\hline
\end{tabular}

* Significant at $\mathrm{p}=0.01$

Heritability is the most widely used measure to determine the importance of genetic factors in determining the variation of a quantitative trait (Hedrick, 2005). Heritability measure is specific to a particular trait, organism, environment and population. Mousseau and Roff (1987) summarized data from 1120 heritability estimates in wild outbred animal populations and gave the cumulative frequency distribution of four types of traits i.e. those related to life history, behavior, physiology and morphology. The results suggested that the heritability for traits related to morphology are the largest followed by that for physiol- ogy, behavior and life history. Rh allele frequency could be considered as a morpho-physiological trait for human identification. The traits that have been under stronger selection during evolution show lower heritability and lower genetic variation.

Tab. 3. Genetic parameters of allele frequency of Rh gene

\begin{tabular}{ccccc}
\hline Character & $\begin{array}{c}\text { Env. } \\
\text { Variance }\end{array}$ & $\begin{array}{c}\text { Genotypic } \\
\text { Variance }\end{array}$ & $\begin{array}{c}\text { Heritability } \\
\text { Variance }\end{array}$ & $\begin{array}{c}\text { Phenotypic } \\
(\%)\end{array}$ \\
\hline $\begin{array}{c}\text { Rh allele } \\
\text { frequency }\end{array}$ & 0.015 & 0.079 & 0.094 & 84.04 \\
\hline
\end{tabular}

The estimate of broad sense heritability for Rh allele frequency in the present study was very high (84.04\%) indicating that the role of environment in the variation of $\mathrm{Rh}$ allele frequency over populations was small (15.69\%). Very high heritability estimate of Rh gene frequency over the populations indicated that this trait was under weak selection pressure during the evolutionary history of mankind resulting in greater genetic variation in existing populations. It is consistent with the prediction from Fisher's fundamental theorem of natural selection (Fisher, 1958). It also revealed that selection was not the major factor in changing the allele frequency of Rh gene.

\section{Conclusions}

The results from the present study revealed that $\mathrm{RhD}$ allele occurs nearly 2.33 fold more than the Rhd allele in existing human populations with an average frequency of 0.70 for $\mathrm{RhD}$ and 0.30 for Rhd alleles. Rh gene frequency showed a broad sense heritability estimate of $84.04 \%$ indicating the dominant role of genetic factors and the little role of environmental factors in determining the $\mathrm{Rh}$ allele frequency in human populations. The results further suggested that inbreeding at $\mathrm{RhD} / \mathrm{d}$ locus since initial generation and some evolutionary forces (particularly mutation, migration and random drift) other than selection alone played major roles in changing the $\mathrm{Rh}$ allele frequency in existing populations.

\section{References}

Chakraborty, S. (2010). Genetic analysis on frequency of alleles for Rh and ABO blood group systems in the Barak Valley populations of Assam. Not. Sci. Biol. 2(2):31-34.

Fisher, R. A. (1958). The Genetic Theory of Natural Selection. Dover, New York, USA, pp.133.

Gupta, S. P. (1991). Statistical Methods. Sultan Chand \& Sons Publishers, New Delhi, India, p. A-51-57.

Hedrick, P. W. (2005). Measures of genetic variation. In: Jones and Bartlett (Eds.), Genetics of Populations ( $3^{\text {rd }} \mathrm{Ed}$ ). 
Sudbury, Madison, USA, pp.61-112.

Johnson, H. W., H. F. Robinson and R. E. Comstock (1955). Estimates of genetic and environmental variability in soybean. Agron. J. 47:314-318.

Khattak, I. D., T. M. Khan, P. Khan, S. M. A. Shah, S. T. Khattak and A. Ali (2008). Frequency of ABO and rhesus blood groups in district Swat, Pakistan. J. Ayub. Med. Coll. 20(4) at http://faculty.matcmadison.edu/mljensen/Blood Bank/ lectures/Rh Blood Group System.htm.

Loua, A., M. R. Lamah, N. Y. Haba and M. Camara (2007). Frequency of blood groups $\mathrm{ABO}$ and rhesus $\mathrm{D}$ in Guinean population. Transfus. Clin. Biol. 14(5):435-439.

Mourant, A. E., A. C. Kopec and K. Domaniewska-Sobczak (1976). The Distribution of Human Blood Groups and Other Polymorphisms $\left(2^{\text {nd }} E d\right)$. Oxford University Press, New York, USA.
Mousseau, T. A. and D. A. Roff (1987). Natural selection and the heritability of fitness components. Heredity 59:181197.

Saran, R. K. (2003). Rh blood group system. In: Transfusion Medicine Technical Manual. Ministry of Health and Family Welfare, Govt. of India, New Delhi, India. pp.75-87.

Singh, B. D (1990). Population genetics. In: Fundamentals of Genetics. Kalyani Publishers, New Delhi, pp.676-704.

www.blood type facts, discussion forum and encyclopedia article.htm.

www.ncbi.nlm.nih.gov.

www.reference for blood type-search_com. 